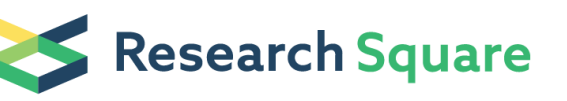

\title{
Dynamic Response of Existing R.C. Bridges Against Earthquake Forces
}

Manasa J ( $\sim$ jmanasaj9@gmail.com )

A.P State Government

\section{KodandaRamarao $\mathbf{P}$}

Seshadri Rao Gudlavalleru Engineering college

\section{A Srinivasulu A}

seshadri Rao Gudlavalleru Engineering college

\section{Reddy S R K}

Seshadri Rao Gudlavalleru Engineering college

\section{Research Article}

Keywords: Seismic response, IS1893-(Part -3) 2014, Abutment \& Pier, Time period, Displacement and Base shear

Posted Date: January 31st, 2022

DOI: https://doi.org/10.21203/rs.3.rs-1308865/v1

License: (c) (1) This work is licensed under a Creative Commons Attribution 4.0 International License. Read Full License 


\title{
Dynamic Response of Existing R.C. Bridges Against Earthquake Forces
}

\author{
J Manasa $^{1}$, P KodandaRamarao ${ }^{2}$, A.Srinivasulu ${ }^{3}$, S.R.K.Reddy ${ }^{4}$ \\ ${ }^{1 *}$ Village Surveyor, A.P. State Government, Vijayawada, India. \\ ${ }^{2}$ Vice Principal, Department of Civil Engineering, Seshadri Rao Gudlavalleru \\ Engineering College, GUDLAVALLERU, A.P, India \\ ${ }^{3}$ Head of the Department, Department of Civil Engineering, Seshadri Rao Gudlavalleru \\ Engineering College, GUDLAVALLERU, A.P, India \\ ${ }^{4}$ Adjunct Professor, Department of Civil Engineering, Seshadri Rao Gudlavalleru \\ Engineering College, GUDLAVALLERU, A.P, India \\ Corresponding Author Email; jmanasaj9@gmail.com
}

\begin{abstract}
Performance of bridges against earthquake forces is different from buildings and other kind of structures as bridges are long and narrow, and support fleeting populace on highways or railways. Earthquakes with magnitude greater than 6.0 are capable of damaging or sometimes leading to even collapse of lifeline bridges, resulting in human and socio-economic losses. The extent of earthquake damage depends on the location of bridge close to the nearest seismic zone, structural configuration, ductility demand, age, and characteristics of the soil below foundation. Many failure examples during recent past earthquakes demand the scientific community and civil engineers, the importance of designing bridge structures against seismic forces; particularly when they built on loose soils. Vertical and lateral loads are resisted by the frame action of the superstructure and substructure of the bridge. Abutments and piers or supporting columns resist lateral forces in proportion to their relative stiffness. The vulnerability of any bridge during an earthquake is mainly due to the lateral displacements which cause large shear and flexure in pier or abutment and lead to failure at connections between the pier top and superstructure, or pier bottom and foundation. In the present study, an example of a two-lane and four spanned R.C. Tbeam bridge across a canal, located in seismic zone III, is chosen for carrying out dynamic analysis against seismic forces and checked whether the bearing seat width provided at top of abutment and pier is safe or not, against the horizontal displacement of abutment and pier, obtained from the analysis due to seismic forces.
\end{abstract}

Keywords: Seismic response, IS1893-(Part -3) 2014, Abutment \& Pier, Time period, Displacement and Base shear 


\section{Introduction}

Any bridge, if damaged during an earthquake, can have serious impact on the transport system and also have tremendous consequences since bridges come under important transport infrastructure system. If the abutments and piers are built on soft soils, the ground motion gets amplified during an earthquake and if the soil below the foundation is sandy soil, sometimes it may lead to liquefaction failure. The seismic response of abutments and piers of a bridge depends on their capacity, mass and the dynamic resistance against backfill soil.

The bridges that were built twenty or thirty years back, when checked as per the present seismic code provisions, at least, some of them may be found vulnerable against strong or even moderate earthquakes.

The failure examples during recent earthquakes (figs. 1\&2) have made people to think about the safety of existing bridges. To avoid the possibility of future damages, bridges that are at risk shall be identified, evaluated, and necessary retrofitting measures may be taken up.

$\mathrm{K}$ Andreas et.al. [1] investigated the effect of pile foundation stiffness on lateral displacements, the flexibility of the bridge, and the ductility demand of the pier. Araliya Mosleh et.al. [2] performed non-linear dynamic time-history analyses to identify the seismic vulnerability of typical pre-1990 bridges. Yuandong Wang et.al. [3] suggested seismic retrofit methods of a three-span R.C. bridge introducing Buckling-Restrained Braces (BRB) between bent columns which redistribute and dissipate energy in the transverse direction of the bridge.

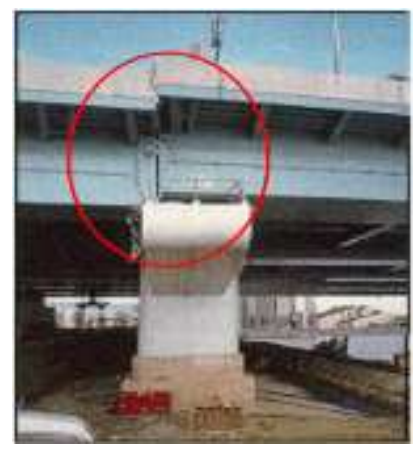

Figure 1 Lateral movement of pier due to soil liquefaction

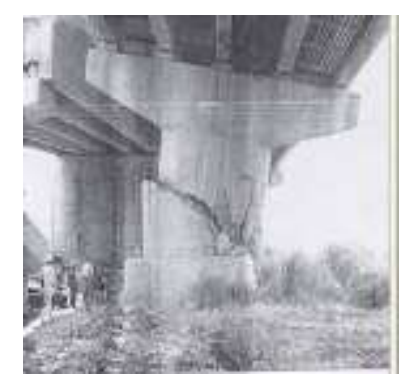


Figure 2 Failure of bridge pier during CHI-CHI, Taiwan earthquake, 1999

\subsection{Objective}

In the present study, the focus is made mainly on the structural behaviour of existing bridges, when they are subjected to earthquake forces. A thirty-year old R.C. T-beam bridge located in seismic Zone III, near Machilipatnam, a coastal town in the state of Andhra Pradesh, India, has been chosen for study, and the dynamic analysis is carried out for obtaining the response parameters like; time period, displacement and base shear of the bridge elements against earthquake loading.

\section{Methodology}

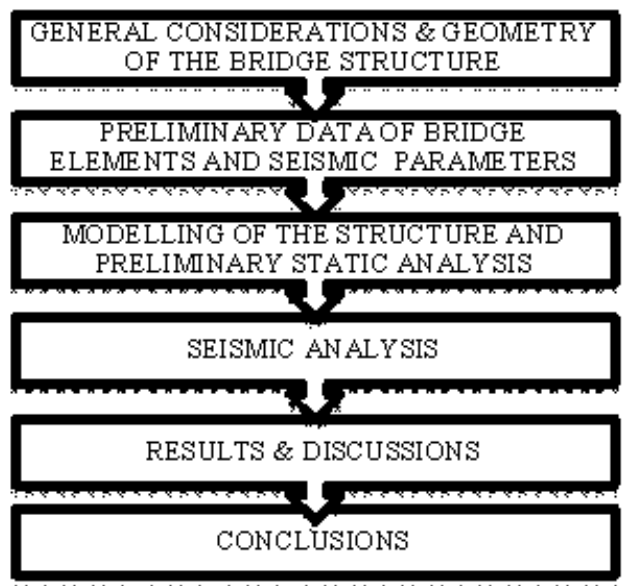

Figure 2

The basic dimensions of structural elements of the chosen bridge are assumed as per the provisions given in IRC-6, 2000 [4] and the seismic analysis is carried out as per IS 1893 (Part 1) 2016 [5] and IS 1893 (Part 3) 2014 [6]. The assumed dimensions are then assigned to the bridge and the analysis, when the bridge is subjected to both dead loads and live loads, is carried out as per IRC code provisions, and checked whether the assumed dimensions are safe or not. Earthquake analysis is carried out for obtaining the seismic parameters like; time periods, displacements and base shears. A cheek is also made whether the bearing seat widths provided at the top of abutment and pier, are safe or not.

\subsection{General considerations}

\subsubsection{Structure details:}

- Preliminary sizes of the bridge components are calculated for dead load and live loads only.

- Though the ground vibrates in all directions during an earthquake, normally horizontal component of the ground motion is more predominant than that of vertical component. 
- Hence, in the analysis, the horizontal component that acts in longitudinal direction of the bridge, is only considered for obtaining horizontal displacements of abutment and pier.

- For all structural elements of bridge, M25 grade concrete and Fe 415 grade steel are used and for abutments and piers M15 grade concrete is used.

\subsection{The Geometry of bridge structure:}

The plan and cross-sectional view of the chosen bridge are shown in figure 3 and 4.

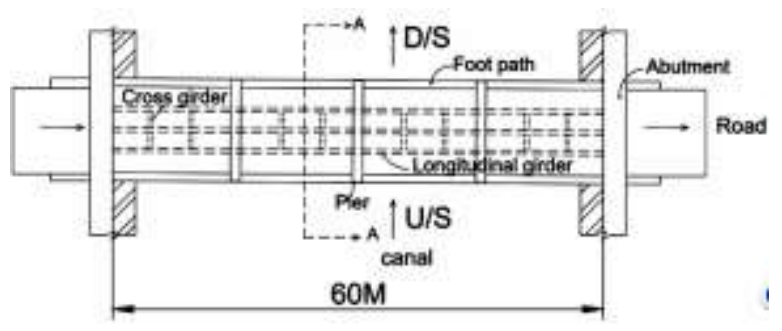

Figure 3 Plan of RC T-Beam Bridge

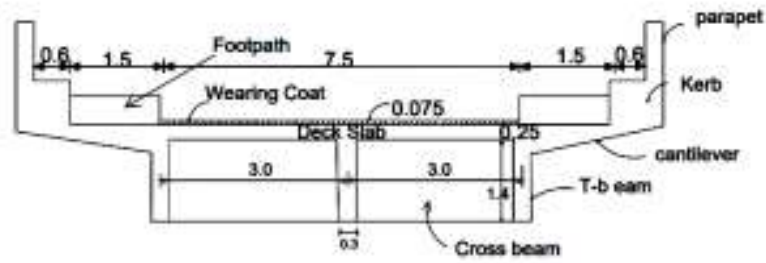

Figure 4 Cross-Section AA

\subsection{Preliminary data}

\subsubsection{Dimensions of structural elements of bridge}

The dimensions of various bridge elements that are considered in the analysis are presented in Table 1.

Table 1 Dimensions of structural members of bridge

\begin{tabular}{|l|l|}
\hline Member & Dimensions \\
\hline $\begin{array}{l}\text { Length of the } \\
\text { bridge }\end{array}$ & $60 \mathrm{~m}$ \\
\hline Width of the bridge & $11.7 \mathrm{~m}$ \\
\hline $\begin{array}{l}\text { Clear Road } \\
\text { Carriage width } \\
\text { (Two-lane) }\end{array}$ & $7.5 \mathrm{~m}$ wide \\
\hline Width of Kerb & $600 \mathrm{~mm}$ \\
\hline
\end{tabular}




\begin{tabular}{|l|l|}
\hline $\begin{array}{l}\text { Thickness of deck } \\
\text { slab }\end{array}$ & $250 \mathrm{~mm}$ \\
\hline $\begin{array}{l}\text { Thickness of } \\
\text { wearing coat }\end{array}$ & $75 \mathrm{~mm}$ \\
\hline $\begin{array}{l}\text { Span between end } \\
\text { bearings }\end{array}$ & $13.8 \mathrm{~m} \mathrm{c} / \mathrm{c}$ \\
\hline Overall span & $15 \mathrm{~m}$ \\
\hline Foot path width & $1.5 \mathrm{~m}$ \\
\hline Abutment height & $3.4 \mathrm{~m}$ \\
\hline $\begin{array}{l}\text { Abutment top \& } \\
\text { bottom widths }\end{array}$ & $\begin{array}{l}1.6 \mathrm{~m} \& 2.4 \mathrm{~m} \\
\text { respectively }\end{array}$ \\
\hline Pier height & $3.4 \mathrm{~m}$ \\
\hline $\begin{array}{l}\text { Pier top \&bottom } \\
\text { widths }\end{array}$ & $\begin{array}{l}2 \mathrm{~m} \& 3 \mathrm{~m} \\
\text { respectively }\end{array}$ \\
\hline
\end{tabular}

The details of various seismic parameters for carrying out the analysis are summarized in Table 2 below

Table 2 Seismic parameters

\begin{tabular}{|l|l|}
\hline $\begin{array}{l}\text { Seismic } \\
\text { Parameter }\end{array}$ & \multicolumn{1}{|c|}{ Value / Reference } \\
RCC & $25 \mathrm{kN} / \mathrm{m}^{3}$ \\
\hline $\begin{array}{l}\text { Unit weight of } \\
\text { fill }\end{array}$ & $20 \mathrm{kN} / \mathrm{m}^{3}$ \\
\hline Location & $\begin{array}{l}\text { Machilipatnam } \\
(\text { Seismic Zone III) }\end{array}$ \\
\hline Earthquake load & $\begin{array}{l}\text { As per IS-1893 (Part } \\
1)-2016\end{array}$ \\
\hline Type of soil & $\begin{array}{l}\text { Type III as per } \\
\text { IS:1893(Part-3) } 2014\end{array}$ \\
\hline Zone Factor & 0.16 \\
\hline Importance Factor & 1.5 \\
\hline Response & 2.5 \\
\hline
\end{tabular}


Reduction Factor

\subsection{Design of bridge elements for dead and live loads}

\subsubsection{Hydraulic particulars of the Bridge}

Soil - Black cotton soil

MSL - $\quad-3.43 \mathrm{~m}$ and $\mathrm{MFL}-\quad+1.53 \mathrm{~m}$

The bridge deck slab and longitudinal T-beam girders are analyzed for IRC class AAloading and checked against IRC Class A-loading. Following the code provisions given in IS 456 (2000), [7] the thicknesses of deck slab as $250 \mathrm{~mm}$, the rib size of each longitudinal girder as $300 \times 1400 \mathrm{~mm}$, and rib size of cross girder as 250x1400mm, are obtained. The final dead \& live load moments and shear force values are calculated for both class AA and class A loadings and the values are presented in Tables $3 \& 4$.

Table 3 Design Moments

\begin{tabular}{|c|c|c|c|}
\hline Type of & B.M & B.M & Total \\
girder & Dead & live & B.M \\
& load & load & $(\mathrm{kN}-\mathrm{m})$ \\
& $(\mathrm{kN}-\mathrm{m})$ & $(\mathrm{kN}-$ & \\
\hline
\end{tabular}




\begin{tabular}{|c|c|c|c|}
\hline $\begin{array}{c}\text { Outer } \\
\text { girder }\end{array}$ & 1335 & 1534 & 2869 \\
\hline $\begin{array}{c}\text { Inner } \\
\text { girder }\end{array}$ & 1335 & 924 & 2259 \\
\hline
\end{tabular}

Table 4 Design Shear forces

\begin{tabular}{|c|c|c|c|}
\hline $\begin{array}{c}\text { Type of } \\
\text { girder }\end{array}$ & $\begin{array}{c}\text { S.F } \\
\text { dead } \\
\text { load } \\
(\mathbf{k N})\end{array}$ & $\begin{array}{c}\text { S.F } \\
\text { live } \\
\text { load } \\
(\mathbf{k N})\end{array}$ & $\begin{array}{c}\text { Total } \\
\text { S.F } \\
(\mathbf{k N})\end{array}$ \\
\hline $\begin{array}{c}\text { Outer } \\
\text { girder }\end{array}$ & 365 & 204 & 569 \\
\hline $\begin{array}{c}\text { Inner } \\
\text { girder }\end{array}$ & 365 & 123 & 488 \\
\hline
\end{tabular}

For the above maximum B.M and S.F values, the sections of the T-beam girders are worked out as per the provisions given in IS 456 (2000) code and the assumed dimensions of Tbeams are found satisfactory.

\subsection{Design of Abutment:}

\subsubsection{Active earth pressure on abutment}

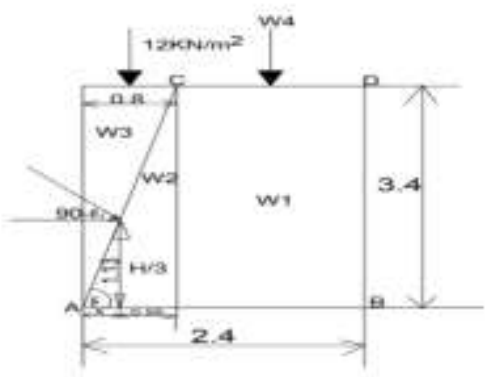

Figure 5 Forces acting on the abutment for active earth pressure

It is assumed that the bottom and top width of abutments as $2.4 \mathrm{~m}$ and $1.6 \mathrm{~m}$ respectively and the horizontal component of earth pressure is calculated.

To calculate the slanted slope of the abutment $(\beta)$,

From fig $5, \tan \beta=\frac{3.4}{0.8} ; \beta=76.45^{\circ}$ and $\alpha=13.55^{0}$

Coulomb's active earth pressure for cohesion-less soils 


$$
\begin{aligned}
& P_{a}=\frac{1}{2} k_{a} \gamma H^{2} ; \text { Where } k_{a}=\frac{1-\sin \emptyset}{1+\sin \emptyset}=0.33 \\
& P_{a}=\frac{1}{2} k_{a} \gamma H^{2}=\frac{1}{2} \times 0.33 \times 20 \times(3.4)^{2}=38.15 \mathrm{KN} \\
& P_{H}=P_{a} \cos \left(13.55^{0}\right)=38.15 \cos \left(13.55^{0}\right)=37.09 \mathrm{KN} \\
& P_{V}=P_{a} \sin \left(13.55^{0}\right)=38.15 \sin \left(13.55^{\circ}\right)=8.94 \mathrm{KN}
\end{aligned}
$$

\subsubsection{Passive earth pressure on abutment}

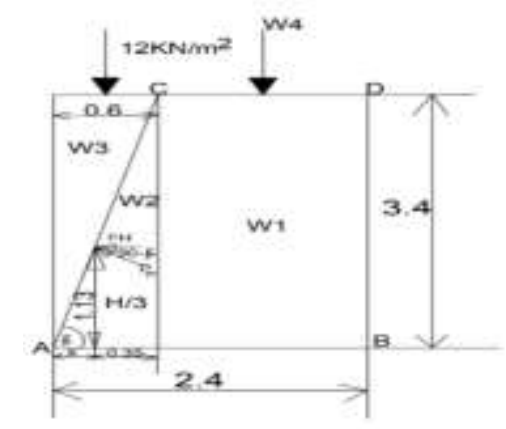

Figure 6 Forces on Abutment for passive earth pressur

\section{Coulomb's passive earth pressure for cohesionless soils From fig 6 ,}

$P_{a}=\frac{1}{2} k_{a} \gamma H^{2}$

Where, $k_{a}=\frac{1+\sin \emptyset}{1-\sin \varnothing}=3$

$P_{a}=\frac{1}{2} k_{a} \gamma H^{2}=\frac{1}{2} \times 3 \times 20 \times(3.4)^{2}=346.8 \mathrm{KN}$

$P_{H}=P_{a} \cos \left(10.41^{0}\right)=346.8 \cos \left(10.41^{0}\right)=341.09 \mathrm{KN}$

$\mathrm{P}_{\mathrm{V}}=P_{a} \sin \left(10.41^{0}\right)=346.8 \sin \left(10.41^{0}\right)=62.66 \mathrm{KN}$

The stability analysis of the abutment is carried out and the check against sliding and no tension at the base is done and found safe.

\subsection{Design of pier}

Reaction due to water pressure (buoyancy),

$\mathrm{P}=0.5 \mathrm{~h}^{2} \mathrm{x}$ Density of water

$=0.5 \mathrm{x}(2.8)^{2} \times 10=39.2 \mathrm{KN}$

To calculate the slanted slope of the pier,

From fig. $7, \tan \beta=\frac{3.4}{0.5}$; and $\beta=81.38^{0}$

$\alpha=90^{0}-\beta=8.62^{0}$ 


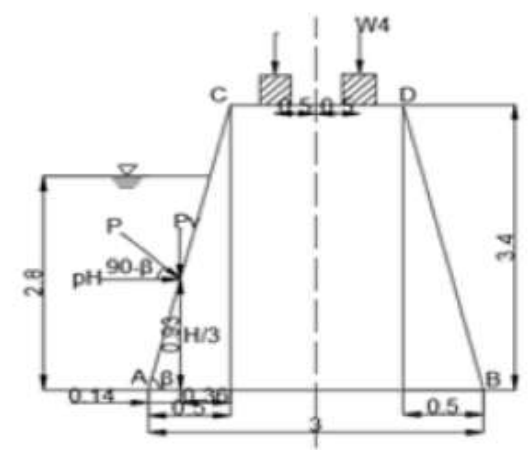

Figure 7 Forces acting on the pie

$P_{H}=\mathrm{P} \cos \left(8.62^{0}\right)=39.2 \cos \left(8.62^{0}\right)=38.76 \mathrm{KN}$

$P_{V}=\mathrm{P} \sin \left(8.62^{0}\right)=39.2 \sin \left(8.62^{0}\right)=5.88 \mathrm{KN}$

The stability analysis of the pier is carried out and the checks against sliding and no tension at the base are done and found safe.

\section{Seismic analysis}

\section{Seismic analysis for horizontal displacement of abutment:}

The vibration unit of abutment can be idealized as a single cantilever carrying the mass of bridge superstructure at top of abutment and supported by open foundation or piles with pile cap at the bottom and the fundamental time period against horizontal displacement at top is calculated as per clause 8.1 of IS 1893 (Part 3) 2014

$$
\mathrm{T}=2 \pi \sqrt{\frac{\delta}{g}}
$$

Where $\delta$ - Horizontal displacement at top of abutment due to horizontal force $(\mathrm{mg})$

$\mathrm{m}$ - Lamped mass at top of the abutment transmitted from bridge superstructure $\mathrm{g}-$ Acceleration due to gravity

It is assumed that abutment is fixed at foundation level and free at top. The load from bridge superstructure, assigned at the top of abutment is calculated considering the weights of deck slab, footpath, kerb, parapet, wearing coat, longitudinal \& cross girders along with 70R live load.

Total weight obtained, $\mathrm{W}=1745.0 \mathrm{kN}$

Mass ' $\mathrm{m}$ ' at top of abutment $=1745 / 9.81=77.9 \mathrm{kN}-\mathrm{s}^{2} / \mathrm{m}$

M 15 grade concrete is assumed for abutment \& pier for which 
$\mathrm{E}_{\mathrm{c}}=5000 \sqrt{15}=19365 \mathrm{~N} / \mathrm{mm} 2$, say $19.4 \times 10^{6} \mathrm{kN} / \mathrm{m}^{2}$

\subsubsection{Time period of abutment}

Load from bridge superstructure assigned at the top of abutment:

DL due to deck slab $=\frac{15}{2} \times 6.3 \times 0.25 \times 25 \quad=295.3 \mathrm{kN}$

DL due to cantilever slab $=\frac{15}{2} \times \frac{2 \times 2.7}{2} \times 0.25 \times 25$

$$
=26.6 \mathrm{kN}
$$

DL due to Kerbs $=\frac{15}{2} \times 2 \times 0.6 \times 0.5 \times 25 \quad=112.5 \mathrm{kN}$

DL due to wearing coat $=\frac{15}{2} \times 0.075 \times 7.5 \times 24=101.2 \mathrm{kN}$

DL due to parapet $=\frac{15}{2} \times 0.23 \times 0.8 \times 19.2=26.5 \mathrm{kN}$

DL due to Long girders $=\frac{15}{2} \times 3 \times 0.3 \times 1.4 \times 25=236.3 \mathrm{kN}$

DL due to Cross girder $=2 \times 2 \times 1.4 \times 0.25 \times 25=35.0 \mathrm{kN}$

$$
\text { Total DL }=1044.5 \mathrm{kN}
$$

Say total DL $=1045.0 \mathrm{kN}$

$$
\text { Total LL }=700.0 \mathrm{kN}
$$

Total Dead load \& Live load, $\quad \mathrm{W}=1745.0 \mathrm{kN}$

Mass at top of abutment,

$\mathrm{m}=\frac{W}{g}=\frac{1745}{9.81}=177.9 \mathrm{kN}-\mathrm{s}^{2} / \mathrm{m}$

Horizontal force at top of abutment,

$\mathrm{mg}=1745 \mathrm{KN}$

$\mathrm{k}=\frac{W}{\delta}=\frac{m g}{\delta}$

Where k-stiffness of abutment

Case i: Treating the abutment as cantilever, 


$$
\delta=\frac{W l 3}{3 E I} \text { or } \mathrm{k}=\frac{W}{\delta}=\frac{3 E I}{L 3}
$$

Where L- abutment height $=3.4 \mathrm{~m}$

$\mathrm{I}=\frac{1}{12} \times 11.7 \times 2.4^{3}=13.48 \mathrm{~m}^{4}$

$\mathrm{k}=\frac{3 \times 19.4 \times 10^{\wedge} 6 \times 13.48}{(3.4)^{\wedge} 3}=20 \times 10^{6} \mathrm{kN} / \mathrm{m}$

$\delta=\frac{W}{k}=\frac{1745}{20 \times 10^{\wedge} 6}=87.25 \times 10^{-6} \mathrm{~m}$

Say, $\delta=0.088 \mathrm{~mm}$

$\mathrm{T}=2 \pi \sqrt{\frac{\delta}{g}}=2 \pi \sqrt{\frac{87.25 \times 10-6}{9.81}}=18.74 \times 10^{-3} \mathrm{sec}$

$\mathrm{T}=0.019 \mathrm{sec}$, Frequency, $\mathrm{f}=\frac{1}{T}=\frac{1}{0.019}=52.6 \mathrm{~Hz}$

Considering the location of bridge in seismic zone III

$\mathrm{Z}=0.16, \mathrm{I}=1.2, \mathrm{R}=2.5$ for abutment

From spectral curves given in IS1893 (part-3) 2014,

$$
\frac{S a}{g}=2.5 \text { for loose soil }
$$

$\mathrm{A}_{\mathrm{h}}=\frac{z}{2} \times \frac{I}{R} \times \frac{S a}{g}=\frac{0.16}{2} \times \frac{1.2}{2.5} \times 2.5=0.096$

To obtain total base shear at base of abutment,

$\mathrm{W}=\mathrm{Weight}$ at top of abutment + weight of abutment,

$$
\mathrm{W}=1745+11.7 \frac{(2.4+1.6)}{2} \times 3.4 \times 24=3655 \mathrm{kN}
$$

\section{Base shear at foundation level of abutment}

$\mathrm{V}_{\mathrm{B}}=\mathrm{A}_{\mathrm{h}} . \mathrm{W}=0.096 \times 3655=350.9 \mathrm{kN}$

Case ii) Horizontal displacement of abutment due to shear and flexure,

$$
\delta x=\frac{F H 3}{3 E C I}+\frac{1.2 F H}{A G C}
$$


Total horizontal force acting on abutment $(\mathrm{F})$ is the summation of

a) Base shear against earthquake load

b) Active or passive earth pressure whichever is more and

c) Longitudinal load at $20 \%$ of class AA or class A loading whichever is more

$$
\begin{aligned}
& \mathrm{F}= 350.9+341.09+0.2(700)=1042 \mathrm{kN} \\
& \mathrm{E}_{\mathrm{c}}=19.4 \times 10^{6} \mathrm{kN} / \mathrm{m}^{2} ; \mu=0.2 \\
& \mathrm{E}_{\mathrm{c}}=2 \mathrm{G}_{\mathrm{c}}(1+\mu) \text { and } \mathrm{G}_{\mathrm{c}}=8.08 \times 10^{6} \mathrm{kN} / \mathrm{m}^{2}
\end{aligned}
$$

$\mathrm{I}=13.48 \mathrm{~m}^{4}, \mathrm{~A}=11.7 \times 2.4=28.08 \mathrm{~m}^{2}$ and $\mathrm{H}=3.4 \mathrm{~m}$

Substituting these values in equation (1), $\delta x=0.07 \mathrm{~mm}$

From the above two cases, the maximum value of horizontal displacement of abutment is $0.088 \mathrm{~mm}$.

$\delta x=0.088 \mathrm{~mm}$

\subsubsection{Time period for pier:}

\section{Load from superstructure of bridge transferred to top of the pier:}

DL from two super structures $=2 \times 1045=2090 \mathrm{kN}$

$$
\mathrm{LL}=700 \mathrm{kN}
$$

Total $\mathrm{W}=2790 \mathrm{kN}$

Mass at top of pier, $\mathrm{m}=\frac{W}{g}=\frac{2790}{9.81}=284.4 \mathrm{kN}-\mathrm{s}^{2} / \mathrm{m}$

\section{Case i ) Considering pier as a cantilever}

Stiffness, $\mathrm{k}=\frac{3 E I}{L 3}$

Where $\mathrm{I}=\frac{1}{12} \times 11.7 \times 3.0^{3}=26.325 \mathrm{~m}^{4}$

$$
\text { and } \mathrm{L}=3.4 \mathrm{~m}
$$

$$
\mathrm{k}=\frac{3 \times 19.4 \times 10^{\wedge} 6 \times 26.325}{3.4^{\wedge} 3}=39.0 \times 10^{6} \mathrm{kN} / \mathrm{m}
$$

$\delta=\frac{W}{k}=\frac{2790}{39 \times 10^{\wedge} 6}=71.5 \times 10^{-6} \mathrm{~m}=0.0715 \mathrm{~mm}$ 
Time period, $\mathrm{T}=2 \pi \sqrt{\frac{\delta}{g}}=2 \pi \sqrt{\frac{71.5 \times 10-6}{9.81}}$

$\mathrm{T}=2 \pi \times 2.7 \times 10^{-3}=17 \times 10^{-3} \mathrm{sec}=0.017 \mathrm{sec}$

Frequency, $\mathrm{f}=\frac{1}{T}=\frac{1}{0.017}=58.8 \mathrm{~Hz}$

$\mathrm{A}_{\mathrm{h}}=\frac{Z}{2} \cdot \frac{I}{R} \cdot \frac{S a}{g}$

From spectral curves of IS1893 (Part3) 2014,

$\frac{s a}{g}=2.5, \mathrm{Z}=0.16, \mathrm{I}=1.2$ and $\mathrm{R}=2.5$ for pier

$\mathrm{A}_{\mathrm{h}}=\frac{0.16}{2} \times \frac{1.0}{2.5} \times 2.5=0.096$

Total weight $\mathrm{W}=$ weight at top of pier + self weight of pier

$\mathrm{W}=2790+\left(\frac{3.0+2.0}{2}\right) 3.4 \times 24 \times 11.7=5177 \mathrm{kN}$

Base shear at bottom of pier,

$\mathrm{V}_{\mathrm{B}}=0.096 \times 5177=497 \mathrm{kN}$

Case ii ) Displacement of pier under the action of both flexure and shear:

Total horizontal force acting on pier, $\mathrm{F}=497.0+38.8+700(0.2)=675.8 \mathrm{kN}$

$\mathrm{I}=11.7 \times 3.0^{3}=26.325 \mathrm{~m}^{4}$

$\mathrm{A}=11.7 \times 3.0=35.1 \mathrm{~m}^{2}$

$\mathrm{E}_{\mathrm{c}}=19.4 \times 10^{6} \mathrm{kN} / \mathrm{m}^{3} \& \mathrm{G}_{\mathrm{c}}=10.42 \times 10^{6} \mathrm{kN} / \mathrm{m}^{2}$

Substituting above values in Eq, $\delta x=\frac{F H 3}{3 E c I}+\frac{1.2 F H}{A G c}$

$\delta x=0.025 \mathrm{~mm}$ 
From above two cases, the maximum value of horizontal displacement at top the pier is $0.0715 \mathrm{~mm}$

The results of seismic analysis for both abutment and pier are presented in Table 4.

\section{Table-4 Base Shears and Horizontal Displacements}

\begin{tabular}{|c|c|c|}
\hline Parameter & Abutment & Pier \\
\hline Frequency & $52.6 \mathrm{~Hz}$ & $58.8 \mathrm{~Hz}$ \\
\hline Base shear & $350.9 \mathrm{kN}$ & $497.0 \mathrm{kN}$ \\
\hline $\begin{array}{c}\text { Horizontal } \\
\text { displacement }\end{array}$ & $0.088 \mathrm{~mm}$ & 0.0715 \\
$\mathrm{~mm}$ \\
\hline
\end{tabular}

However, as per provisions given in IS 1893 (Part 3) 2014, the minimum bearing seat width $\left(\mathrm{S}_{\mathrm{E}}\right)$ for abutment or pier as in fig 8 , shall be

$\mathrm{S}_{\mathrm{E}}=(203+1.67 \mathrm{~L}+6.66 \mathrm{H}) \mathrm{mm}$ for seismic Zone III

Where

L - Length of superstructure to the adjacent expansion joint or to the end of bridge superstructure. (meters)

$\mathrm{H}$ - Average height of abutment or pier supporting the superstructure to the next expansion joint. (meters)

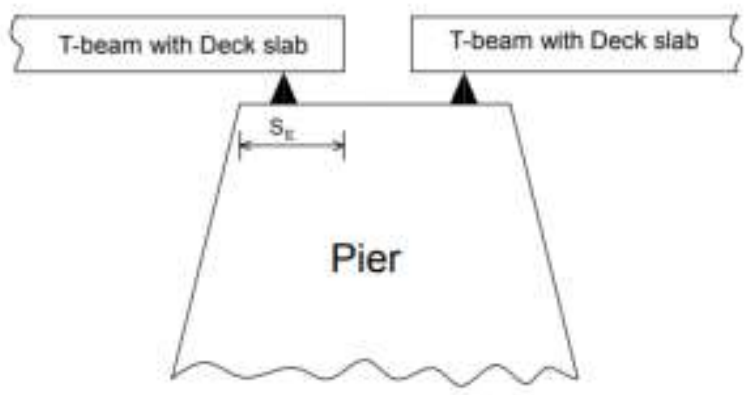

Figure 8 Arrangement of bearings on pier and minimum bearing seat width $\left(\mathrm{S}_{\mathrm{E}}\right)$

Substituting $\mathrm{L}=13.8 \mathrm{~m} \& \mathrm{H}=3.4 \mathrm{~m}$

$\mathrm{S}_{\mathrm{E}}=203+1.67(13.8)+6.66(3.4)=248.7 \mathrm{~mm}$

For both abutment \& pier, 
$\delta_{\text {Calculated }}<\delta_{\min }<\delta_{\text {Provided }}$

$0.088 \mathrm{~mm}<248.7 \mathrm{~mm}<500 \mathrm{~mm}$

Hence the provided edge distance is safe.

\section{Results and Discussions}

From the above results, it is noticed that the variation in frequency components of abutment $(52.6 \mathrm{~Hz})$ and pier $(58.8 \mathrm{~Hz})$, is very less $(12 \%)$.

It is also observed that the base shear due to earthquake motion in pier $(497 \mathrm{kN})$ is more compared to that of in abutment $(350.9 \mathrm{kN})$. This is mainly because the inertia force due to mass at top of pier is more than that of the mass at top of abutment.

The horizontal displacements obtained at top of both abutment and pier $(0.088 \mathrm{~mm})$ due to seismic forces are less and hence the provided bearing seat width both on top of abutment and pier are found safe.

\section{Conclusions}

- During an earthquake, if the calculated displacement at top of abutment or pier is more than that of the minimum bearing seat width as per IS 1893(Part 3) 2014 code, the bridge is not safe.

- Similarly, the displacement of slab both in longitudinal and transverse directions against seismic forces shall be within permissible limits.

- In case, the provided bearing seat width at top of abutment and pier is not sufficient, retrofitting measures need to be taken up by increasing the top width on both sides in case of pier and on canal side only in case of abutment.

\section{References}

1. K Andreas J. Kappos and Anastasios G.Sextos., 2001 "Effects of Foundation and Compliance on seismic response of R.C. Bridges" (ASCE)

2. Araliya Mosleh Mehran S. Razzzaghi Jose Jara HumbertoVarum., 2016 "Seismic fragility analysis of typical pre-1990 bridges due to near- and far-field ground motions" (Springer)

3. Yuandong Wang, S.M. Luis Ibarra, and Chris Pantelides, 2016 "Seismic Retrofit of a ThreeSpan RC Bridge with Buckling-Restrained Braces” (ASCE)

4. IS 1893 (Part-3):2014 Criteria for Earthquake resistant design of structures, Bridges, and retaining walls. 
5. IS 1893 (Part-1):2016 Criteria for Earthquake resistant design of structures, General provisions, and buildings.

6. IRC-6-2000Standard Specifications and Code of practice for Road bridges, section: II Loads and Stresses

7. IS 456: 2000 Plain and Reinforced concrete- Code of practice 